\title{
Effect of Solar Radiation on the Drying Parameters of Mint (Mentha Spicata L.) Dried in Natural Convective Solar Dryer
}

SEBIHA REHMAN ( $\sim$ sebiha09@gmail.com )

National Institute of Technology Srinagar

\section{SEEMIN RUBAB}

National Institute of Technology Srinagar

\section{Research Article}

Keywords: Texture, Enzymatic reactions, Water activity, Moisture content, Convection

Posted Date: December 7th, 2020

DOl: https://doi.org/10.21203/rs.3.rs-117400/v1

License: (c) (i) This work is licensed under a Creative Commons Attribution 4.0 International License.

Read Full License 
Effect of solar radiation on the drying parameters of mint (Mentha spicata L.) dried in Natural convective Solar Dryer

\author{
Sebiha Rehman*, Seemin Rubab** \\ *Research Scholar, Department of Physics, National Institute of Technology, Srinagar J\&K. \\ **Associate Professor, Department of Physics, National Institute of Technology, Srinagar, J\&K. \\ Corresponding Author: sebiha09@gmail.com
}

\begin{abstract}
The paper presents a kinetic study of solar dried mint (Mentha spicata L.) without any pretreatment. Mint grows effortlessly in Kashmir valley but is not obtainable throughout the year because of inconsiderate weather conditions. The genus belongs to the Labiatae family and includes large varieties with different properties. A significant quality parameter is its colour. The drying kinetics of mint leaves dried in Domestic Solar Dryer in terms of colour attributes, moisture content, drying time, non enzymatic browning, water activity, rehydration ratio was studied. This study is very useful for household scale drying of mint leaves to optimize drying process and to achieve superior quality dried product at home maintaining its colour and aroma. Keywords: Texture, Enzymatic reactions, Water activity, Moisture content, Convection Introduction
\end{abstract}

Mint is an aromatic herb having many culinary and medicinal values. The leaf, fresh or dried, has medicinal value. It is used in both fresh and dried forms in different cuisines. The mint leaves are used in a variety of dishes such as chutney, fruit salads, vegetable salads, soups, 
desserts, juices $[1,2,3]$. Dried mint is used in the traditional cooking in Kashmir valley which enhances flavor of the dish. The menthol present in it helps to diminish irritable bowel syndrome symptoms through its relaxing effects on the muscles of the digestive tract [4]. Mint may be effective in relieving other digestive problems such as upset stomach and indigestion.[ 5]. Studies have shown that the mint is used in relieving the nasal congestion [6]. It is also referred that inhaling the aroma of essential oils like mint from the plant could provide health benefits, including improved brain function [7]. This herb has numerous health benefits and grows effortlessly in Kashmir division but cannot be grown during the winter season because of the inconsiderate weather. Kashmir valley experiences more rains and lesser sunny day and experiences harsh winters from the month of November to April [8]. There is abundant growth of vegetables, fruits and herbs during summer season which need to be preserved for further use and in order to avoid the wastage.

Fresh mint is usually preferred over dried mint because storage of the mint is a problem. In order to preserve the herb it is to be dried. Usually people dry it in open sun but as observed from the open sun dried samples the discoloration of herbs and loss of aroma takes place which remains unattractive for the consumer. Moreover the insect, pest infestation, bird droppings, rodent attack etc can takes place. The drying time is very less, even if it is sunny during the day, there are chances of rain in the evening which spoils the drying vegetable. Though open sun drying is the most common practice to dry vegetables in Kashmir Valley during the summer season. Such drying conditions leads to stern losses in the quantity and quality of the dehydrated product. Hence the scientist developed different types solar dryers. The solar drying system utilizes solar energy to heat up air and to dry any food substance loaded, which is beneficial in reducing wastage of agricultural product and helps in preservation of agricultural product. The 
usage of such dryers is limited to the group of researchers and in Kashmir valley people lack the information about such dryers.

Many types of dryers have been developed on the industrial level and are being used for the commercial purpose incurring high capital and maintenance cost. Therefore there is a need to develop a domestic dryer so as to minimize the loss of surplus vegetables produced during the summer season and to preserve the herbs for winter periods with better quality of dried product. The drying of vegetables and fruits is a complex process that is completed in two stages. In the first step evaporation takes place with high speed, eliminating free water, and then drying speed is reduced steadily in proportion to the product moisture reduction as already reported [9] The bound moisture present in the food can become the reason for the fungal growth and reduce the life span. Hence it becomes requisite condition to eliminate the moisture for longer storage of food.

\section{Materials and Method}

Drying of fresh mint is carried out to analyze the drying characteristics. Fresh mint was procured from the local kitchen garden, which is shown in figure 1. It was not de-stemmed and kept as a whole plant, then washed. It is slightly dried with blotting paper. The weight of sample on the sensitive scale was found to be $500 \mathrm{~g}$. It was placed on the mesh trays of the solar dryer which is designed and fabricated from the locally available material. The dryer is natural convective in nature which does not require any external agency for the removal of moisture as it is provide with two vents for inlet and outlet of the warm air. It is constructed from locally available willow wood and is portable weighing $5 \mathrm{~kg}$ which can be lifted easily by everyone. The prototype of dryer can be seen in figure 2 . The moisture content of the herb during the drying process is 
determined by difference in weight of the sample at different stages of drying which is recorded in Figure 3.
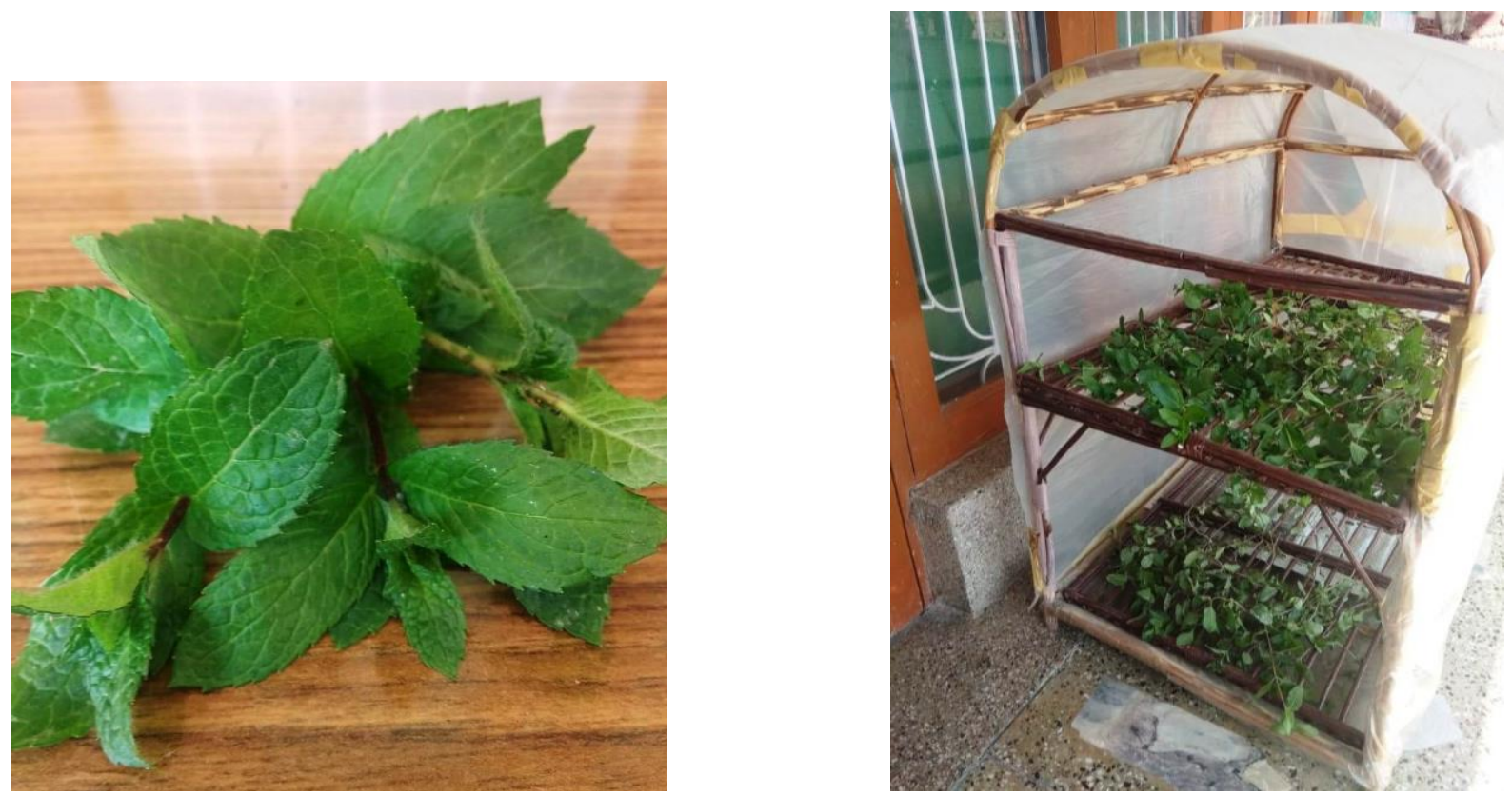

Figure 1: Fresh Mint

Figure 2: Mint drying in Solar Dryer

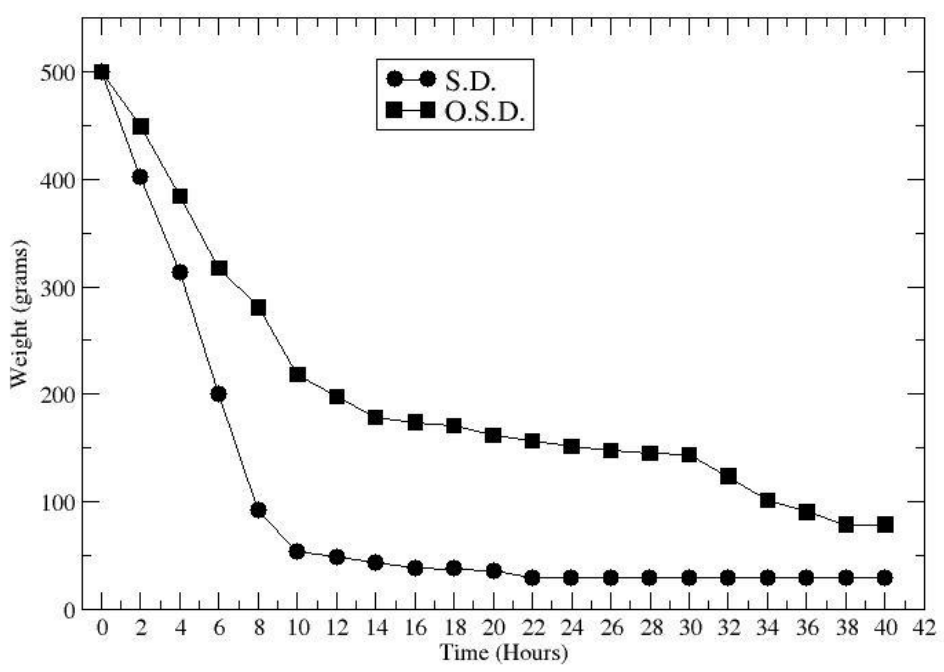

Figure 3: Variation of weight versus drying time 
Reducing the moisture content was recorded by measuring the weight reduction of the mint throughout the drying process. Initially the weight reduced drastically indicating the loss of the moisture content of the sample, gradually the weight reduction became slow. Slow reduction of weight indicates the bound moisture being dehydrated in the product. The longevity of the dried samples increases by the use of solar dryer. The aroma, colour and other parameters remain intact in the sample when properly preserved.

\section{Quality evaluation}

The quality evaluation of any dried food products is determined by its color, brightness, texture changes, water activity, moisture content and stability over time. The parameters have certain standards which the prototype should adhere to. The quality analysis was done on the basis of following parameters:

\section{Determination of Colour}

Colour has an important role in food acceptability by the consumer, and it may influence taste, perception of sweetness, and pleasantness [10]. Hence, it is a very imperative quality factor in processed vegetable products to influence consumer acceptability. Numerous reactions take place during thermal processing which affect the colour of the product. The most common are chlorophyll pigment degradation and browning reactions such as Maillard reaction and oxidation of ascorbic acid [11].

Quality of dried mint was evaluated on basis of colour and the parameters of colour (lightness $\left(L^{*}\right)$, redness $\left(a^{*}\right)$, yellowness $\left(b^{*}\right)$ for the vegetables) were measured at the start and the end of the drying period, using colour difference meter. For reference white tile was used and values of $L^{*}, a^{*}, b^{*}$ were recorded for the same. According to the colour meter model, the $L^{*}$ measures the whiteness, ranges from (black at 0 to white at 100). The $a^{*}$ measures green when negative and 
red when positive and the $b^{*}$ measures blue when negative and yellow when positive. Hue angle, $h^{*}$ is the attribute of colour that is related to the perceived colours: red, yellow, green and blue or a combination of two of them, and measures the color the eye is able to perceive and is given by equation (5) [12]. The colour parameters are related to the browning reaction where a decrease in $L^{*}$ values, and increase in $a^{*}$ values and a decrease in $h^{*}$ values indicate more browning [13, 10]. The High value of Hue angle indicates less browning and vice versa, while chroma is a measurement of strength of colour such as intensity or saturation. [14]

The values of $\Delta \mathrm{E}$, Hue angle and chroma were calculated using the equations $1,2,3,4,5$ given below.

$$
\begin{aligned}
& C^{* 2}=\sqrt{\left(a^{* 2}+b^{* 2}\right)} \\
& \Delta E=\sqrt{\left(L^{*}-L_{r e f}^{*}\right)^{2}+\left(a^{*}-a_{r e f}^{*}\right)^{2}+\left(b^{*}-b_{r e f}^{*}\right)^{2}} \\
& H^{*}=\tan ^{-1}\left\{\frac{b^{*}}{a^{*}}\right\} \quad \text { for } a>0, b>0 \\
& H^{*}=180+\tan ^{-1}\left\{\frac{b^{*}}{a^{*}}\right\} \quad \text { for } a<0, b>0 \& a<0, b<0 \\
& H^{*}=360+\tan ^{-1}\left\{\frac{b^{*}}{a^{*}}\right\} \quad \text { for } a>0, b<0
\end{aligned}
$$

The values of Chroma, hue Angle and $\Delta \mathrm{E}$ are summarized in Table 1.The results given in table indicates the better results for the samples dried in the solar dryer in terms of colour which is evident in the Figure 4 and Figure 5 also, hence more acceptance by the consumers. 


\begin{tabular}{|c|c|c|c|c|c|c|}
\hline Herb & \multicolumn{5}{|c|}{ Colour Parameters } \\
\hline Mint & $\mathrm{L}^{*}$ & $\mathrm{a}^{*}$ & $\mathrm{~b}^{*}$ & $\mathrm{H}^{*}$ & $\mathrm{C}^{*}$ & $\Delta \mathrm{E}$ \\
& & & & & & \\
\hline Fresh & 45.22 & -15.63 & 57.3 & 254.742 & 59.39 & 41.245 \\
\hline Open sun dried & 16.29 & -4.58 & 55.68 & 265.29 & 55.868 & 34.42 \\
\hline . Solar dried & 22.30 & 0.54 & 39.06 & 261.38 & 28.562 & 6.79 \\
& & & & & & \\
\hline
\end{tabular}

Table 1: Colour parameters for fresh, solar dried and open sun dried mint

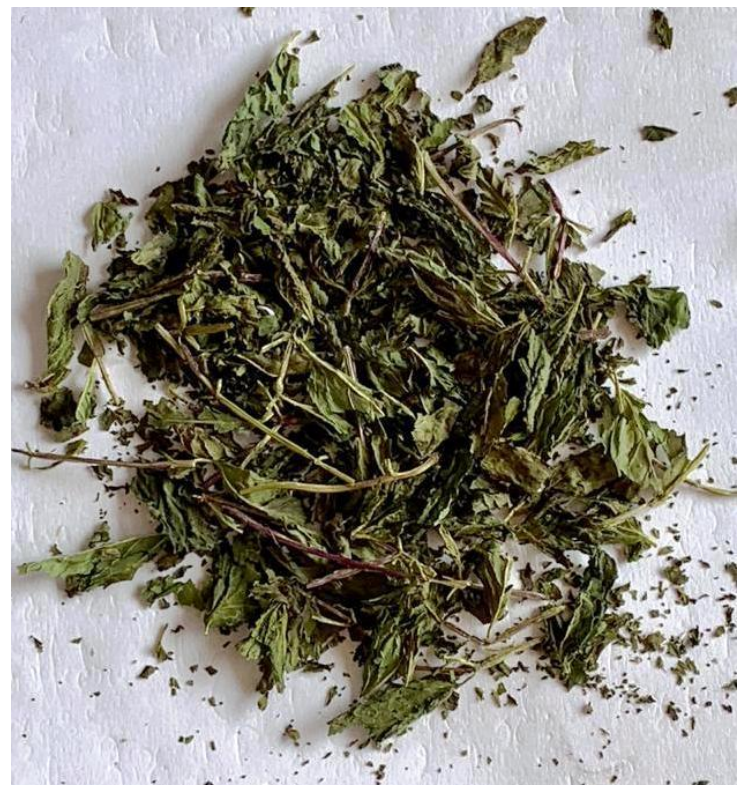

Figure 4: Solar Dried Sample

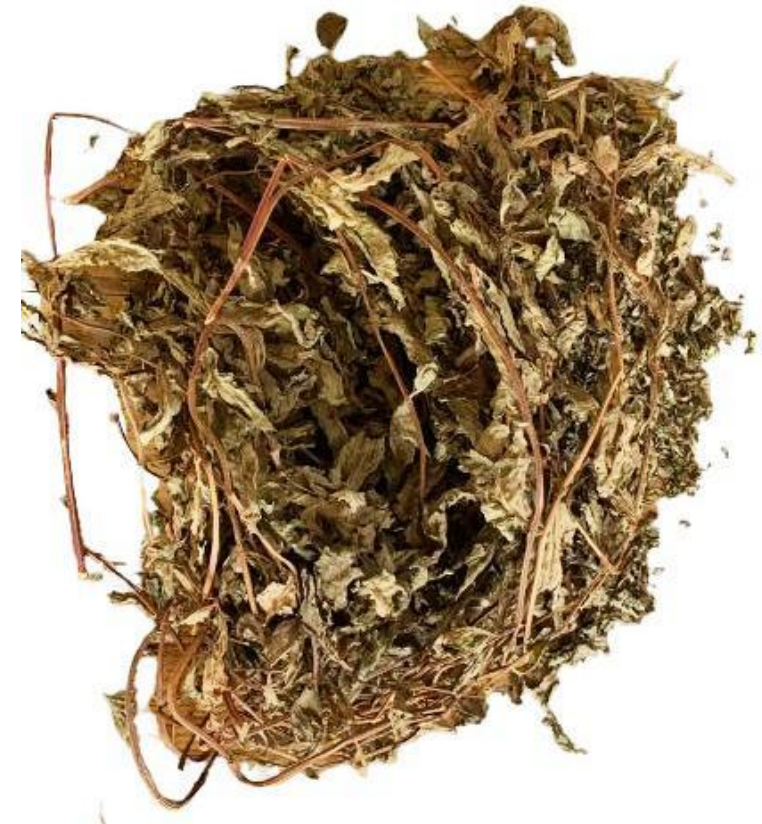

Figure 5: Open Sun Dried Sample

\section{Texture Changes}

Texture is an important parameter of vegetables especially in herbs which is also related to colour. The drying affects the texture in the herbs because of the changes in the cell wall and the 
vacuole of the cell changes in size. Properties of middle lamella and turgor pressure are the significant parameters to determine the texture of the tissue which is already present in the reference. $[15,16]$

\section{Water Activity determination}

Water Activity (aw) is one of the most important factor in determining quality and safety of food For all food stuffs there exists water activity limit below which microorganisms are prevented from growing [17]. It affects the shelf life, safety, texture, flavor and smell of foods. By dropping the value of water activity spoilage of herb can be reduced to huge extent. On performing the water activity analysis it is observed Solar dried sample of mint has the water activity value of 0.503 while it was 0.536 for open sun dried sample which is higher in comparison to solar dried sample.

\section{Moisture Content}

The water content in the herbs becomes one of the main causes for their spoilage during the course of storage. If the value of moisture content in food exceeds $10 \%$ it leads to growth of microorganisms in food [18]. Therefore it becomes imperative to trim down the value of moisture content in order to boost the shelf life of the product. Thus for this reason samples of mint were dehydrated in the Solar Dryer and in the open sun. The loss of water content is determined by the weight loss which is expressed in the figure 3. Moisture content analysis was done on the Halogen based Moisture analyzer. Initial moisture content of the mint is $79 \%$. The 5 g sample of open sun dried mint was powdered and placed in the tray of pre-heated Moisture Analyzer and the chamber was sealed. The moisture content value was found to be $10.72 \%$ for open sun dried sample. For the samples dried in Solar Dryer, it was found that the moisture 
content reduced to $6.05 \%$ which seems to be better value in contrast to the open sun dried value. The variation of moisture content versus drying time is plotted and expressed in figure 6 .

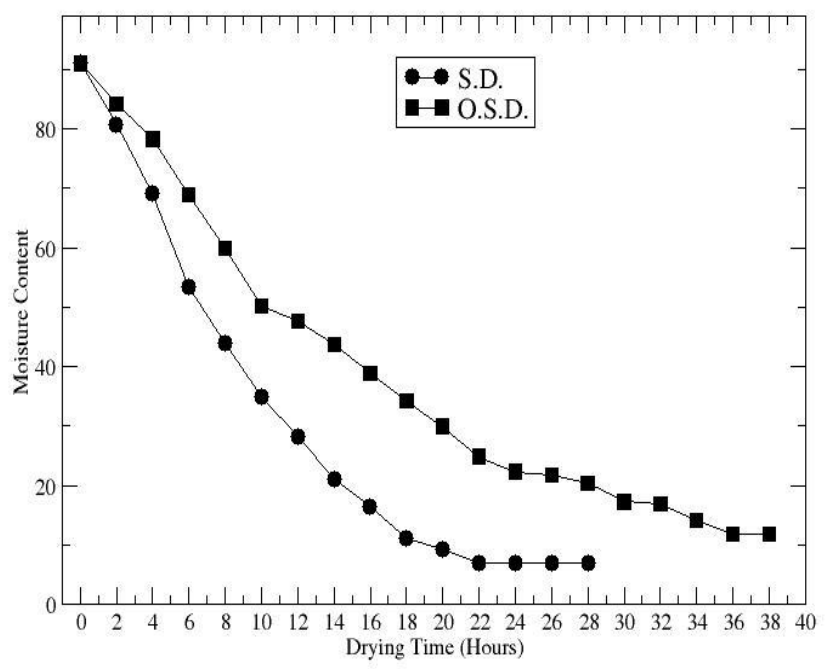

Figure 6: Variation in the moisture content of open sun dried sample and solar dried sample

\section{Rehydration Ratio}

Rehydration test is done by dipping $5 \mathrm{~g}$ of sample in $60 \mathrm{ml}$ of water separately in a beaker and covered with a watch glass. The sample is heated gradually and brought to boil. Boiling continued for 20 minutes which allow the sample to rehydrate and absorb water sufficiently. The sample is removed from the water and excess water is strained from the sample. The rehydrated mint is weighed again. The rehydration ratio is calculated using the formula given by expressed as equation 6. [19]

Rehydration ratio $=\quad \mathrm{W}_{\mathrm{b}} / \mathrm{W}_{\mathrm{a}}$

$\mathrm{W}_{\mathrm{b}}=$ weight of sample after rehydration 
$\mathrm{W}_{\mathrm{a}}=$ weight of sample before rehydration

Rehydration results shows that solar dried sample is rehydrated better in comparison to the open sun dried sample as is depicted in figure 7.

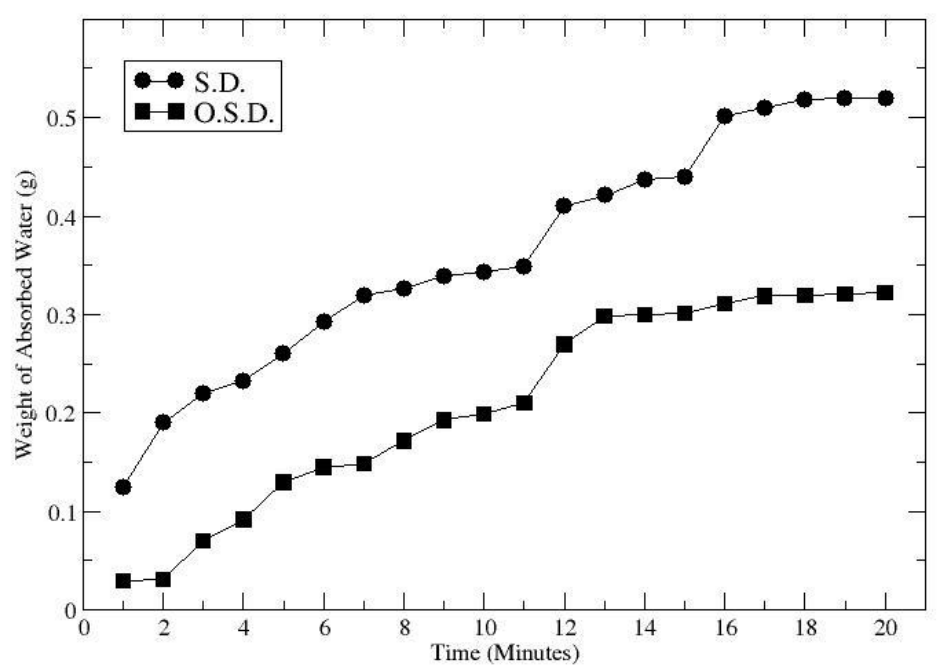

Figure 7: Rehydration value of solar dried and open sun dried samples.

\section{Shrinkage}

During drying process the loss of moisture from vegetable leads to structural collapse, shape deformation and capillary contraction [20]. This shrinkage of vegetables depends on the loss of the moisture from the cells. The shrinkage of food materials during drying is a common physical phenomenon which affects the textural quality and taste of the dried product. The shrinkage of food material depends on many factors like material characteristics, mechanical properties, micro-structure, and drying conditions as calculated by Mohiuddin [21].

The shrinkage is measured by the equations 7 and 8 . 


$$
S=\frac{V}{V_{0}}
$$

Where $\mathrm{V}=$ Initial Volume of the product

$$
\mathrm{V}_{\mathrm{o}}=\text { Final Volume of the product }
$$

The shrinkage percentage is measured in terms of equation

$S K G(\%)=\left(1-\frac{V}{V_{0}}\right) \times 100$

The observed value for the shrinkage were measured and it was found that the solar dried samples show better results in comparison to that of the open sun dried samples and shrinkage is related with the rehydration values, lesser shrinkage leads to better rehydration.

\section{Determination of Ascorbic Acid (Vitamin C)}

The dried samples were tested for the presence of Ascorbic acid, in order to find out how much of vitamin is vanished due to drying. The determination of Ascorbic acid in the fresh and the dried samples was done by 2,4-Dichlorophenol Indo-phenol dye method. The dried samples were soaked separately for few hours and ground to make a paste so that the content of vitamin will be determined perfectly. The samples dried in open sun showed the colour change of titer at just $1 \mathrm{ml}$ indicating absence of Ascorbic acid in the sample The Solar dried sample gave titer value at $4 \mathrm{ml}$ leading to the presence of Vitamin $\mathrm{C}$ around (3- $4 \mathrm{mg}$ ) per $100 \mathrm{~g}$ which is low value but enhanced than open sun dried sample. It indicates that during cutting, washing, drying of mint Vitamin C is reduced, as it is water soluble vitamin. Moreover it indicates that the open sun drying completely destroys the Vitamin C content in the food. Vitamin C is heat and light 
sensitive vitamin and its loss depends on the exposure to light and the duration for which it is exposed to light $[22,23]$

\section{Browning Reactions}

Browning in the eatables is high at water activity value of $0.5-0.8[24,25]$ which lead to the Milliard reactions in the food products. The value of absorbance of UV in the sample extract at $420 \mathrm{~nm}$ wavelengths is taken as a measure of non enzymatic browning. The samples of $5 \mathrm{~g}$ of dehydrated mint were soaked in $100 \mathrm{ml}$ of $60 \%$ alcohol for $24 \mathrm{hrs}$ and then filtered. Absorbance of the filtrate was recorded at $420 \mathrm{~nm}$ with the help of a UV-spectrophotometer using $60 \%$ alcohol as blank and the observation is expressed in terms of optical density given by [26] The analysis done revealed that the samples dried in open sun has more browning in comparison to the samples dried in Solar Dryer. The absorbance and transmittance of the sample is given in Table 2 and comparison can be seen in Figure 8. The change in color is linked with the changing nutritional value. The solubility cause degradation of flavor and induces textural changes.

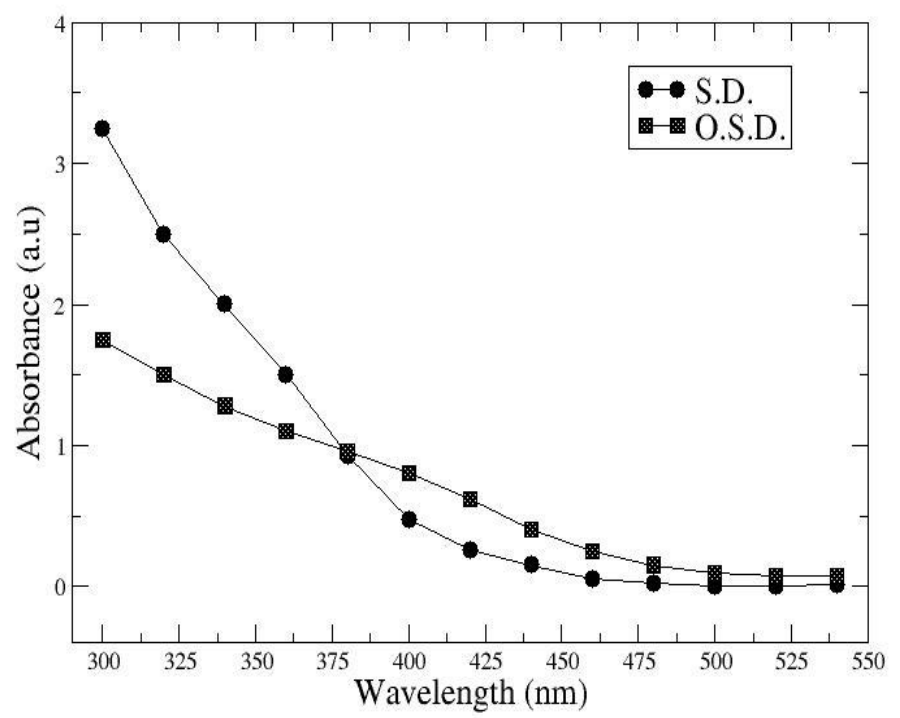


Figure 8: Variation of Absorbance with Wavelength indicating the transmittance.

\begin{tabular}{|l|l|l|l|l|l|l|}
\hline S.No & Type & $\begin{array}{l}\text { Moisture } \\
\text { content }\end{array}$ & $\begin{array}{l}\text { Water } \\
\text { Activity }\end{array}$ & Vitamin C & Absorbance & Transmittance \\
\hline 1 & Fresh & $89 \%$ & 0.964 & $18 \mathrm{mg} / 100 \mathrm{~g}$ & - & - \\
\hline 2 & $\begin{array}{l}\text { Open } \\
\text { Sun } \\
\text { Dried }\end{array}$ & $10.72 \%$ & 0.536 & Nil & 0.516 & $30 \%$ \\
\hline 3 & $\begin{array}{l}\text { Solar } \\
\text { Dried }\end{array}$ & $6.05 \%$ & 0.503 & $3-4 \mathrm{mg} / 100 \mathrm{~g}$ & 0.063 & $85-90 \%$ \\
\hline
\end{tabular}

Table 2:- Proximate Composition of Raw \& Dried Mint

\section{Conclusion}

Dried mint is widely used throughout the globe for its medicinal importance, aroma and flavor.

Usually the preferred drying method is to dry the herb in open sun which leads to the discoloration of the herb. There are different type of dryers available but they incur high capital and maintenance cost. The Prototype of fabricated Solar dryer prevent samples from the direct exposure of the UV rays and hence preserve samples from discoloration. Moreover the drying time is reduced which is required condition while taking the atmospheric condition into consideration. The drawbacks of open sun drying are reduced by the solar drying and preserve 
the nutritive values of the samples. The reduction in the water activity and moisture content of the solar dried sample indicate that the sample can be preserved for longer duration.

\section{References}

[1] The Columbia Electronic Encyclopedia, Columbia: Columbia University Press, 2005.

[2] Park KJ, Vohnikova Z, Brod FPR, Evaluation of drying parameters and desorption isotherms of garden mint leaves (Mentha crips L.). J. Food Eng., 51: 193-199,2002.

[3] Thompson A K Fruits and vegetables (2nd ed.) pp: 273. Oxford: Blackwell Publishing, UK, 2003.

[4] Merat S, Khalili S, Mostajabi P, Ghorbani A, Ansari R, The effect of enteric-coated, delayed-release peppermint oil on irritable bowel syndrome. Dig Dis Sci. 55(5):1385-90. doi: 10.1007/s10620-009-0854-9. Epub 2009 Jun 9. PMID: 19507027, 2010.

[5] Dalvi S S, Nadkarni P M, Pardesi R, Gupta K C. Effect of peppermint oil on gastric emptying in man: a preliminary study using a radio labelled solid test meal. Indian $\mathrm{J}$ Physiol Pharmacol; 35(3):212-4. PMID: 1791066, 1991.

[6] Eccles R, Jawad MS, Morris S. The effects of oral administration of menthol on nasal resistance to airflow and nasal sensation of airflow in subjects suffering from nasal congestion associated with the common cold. J Pharm Pharmacol. ;42(9):652-4. doi: 10.1111/j.2042-7158.1990.tb06625.x. PMID: 1981905,1990.

[7] Moss M, Hewitt S, Moss L, Wesnes KModulation of cognitive performance and mood by aromas of peppermint and ylang-ylang. International Journal of Neuroscience. 118 (1):59-77. doi: 10.1080/00207450601042094. PMID: 18041606. 2008. 
[8] Bhat H. A., Rubab S., A study of domestic energy usage patterns in the Kashmir valley: pilot survey of households, International journal of Ambient Energy, volume 30( 3) 1251362009.

[9] Doymaz I. Convective air drying characteristics of thin layer carrots. Journal of Food Eng; 61(3):359-64, 2004.

[10] Hawlader, M.N.A Perera,. C.O and Tian M, Properties of modified atmosphere heat pump dried foods. Journal of Food Engineering, 74: 392- 401, 2006.

[11] Barreiro J.A, Milano M, and Sandoval A.J., Kinetics of colour change of double concentrated tomato paste during thermal treatment. Journal of Food Engineering. 33 (1): 359-371, 1997.

[12] Mohammadi, A. Rafiee S, Emam-Djomeh Z, and Keyhani, A. "Kinetic models for colour changes in Kiwifruit slices during hot air drying".World Journal of Agricultural Sciences, 4 (3): 376-383, 2008.

[13] Rocha A., and. Morais, A. Shelf life of minimally processed apple (cv. Jonagored) determined by colour changes.2003.

[14] Villamiel, M., del Castillo, M.D. and Corzo, N., Browning Reaction in Food Biochemistry \& Food Processing edited by Hui, Y.H. USA: Blackwell Publishing, 2006.

[15] Jackman R.L., Stanely D.W., Perspectives in the textural evaluation of plant foods, Trends in Food Science nad Technology, 6(6), pp 187 - 194,1995.

[16] Chiralt, A. Martinez- Navarette, N. Martinez- Monzo, J, Talens, P. Morago, G. Ayala A. Fito, P., Changes in mechanical properties throughout osmotic processes, Cyroprotectant effect, Journal of food engineering, 49 (2-3). Pp 129-1352001. 
[17] Sachin V., Jangam, Chung Lim Law, Drying of Foods, vegetables and Fruits (Volume 1), ISBN 978-981-08-6759-1, 2010.

[18] Ong, S.P. and Law,C.L. Hygrothermal Properties of various Foods, Vegetables and Fruits, in DryingofFoods, Vegetables and Fruits- Volume 1, Ed. Jangam, S.V.,Law, C.L. and Mujumdar, A.S., ISBN - 978-981-08-6759-1, Published in Singapore, pp. 31-58. 2010.

[19] Srivastava R. P., Kumar S. Fruits and Vegetable Preservation Methods and Practices, (International Book Distribution Co, Luckhnow), 1993.

[20] Mayor L, Sereno A.M., Modelling Shrinkage During Convective Drying of Food Materials: A Review: Journal of Food Engineering 61 (3): 373 - 3862004.

[21] Mohiuddin M., Imran M., Khan H, Comprehensive Reviews in Food Science and Food Safety Shrinkage of Food Materials During Drying: Current Status and Challenges(2018).

[22] Tannenbaum, S.R.,Young V.R., Archer, M.C., Vitamins and Minerals, In Food Chemistry edited by Fennena, O.R., New York Marcel Dekker, Inc. 1985.

[23] Gupta M.K., Sehgal V.K. et al, Effect of process parameters and storage length on quality of dried cauliflower during storage, Indian Journal of Traditional Knowledge,

Vol. 11(1), 177-184 2012.

[24] Topuz, A. A novel Approach fo Color Degradation Kinetics of Paprika as a function of Water Activity. LWT-Food Scienceand Technology41 (9): 1672-1677. 2008.

[25] Lueng, H.K.,. Influence of Wter Activityy on Chemical Reactivity. In Water Activity: 
Theory and Application to Food, edited by by Rockland, L.B., and Beuchat, L.R., New York; Marcel Dekker, Inc. 1987

[26] McMinn, W.A.M and Magee, T.R.A., Kinetics of Ascorbic Acid Degradation and NonEnzymatic Browning in Potatoes; Food and Bioproducts Processing 75 (4); 223-231. 1997. 
Figures

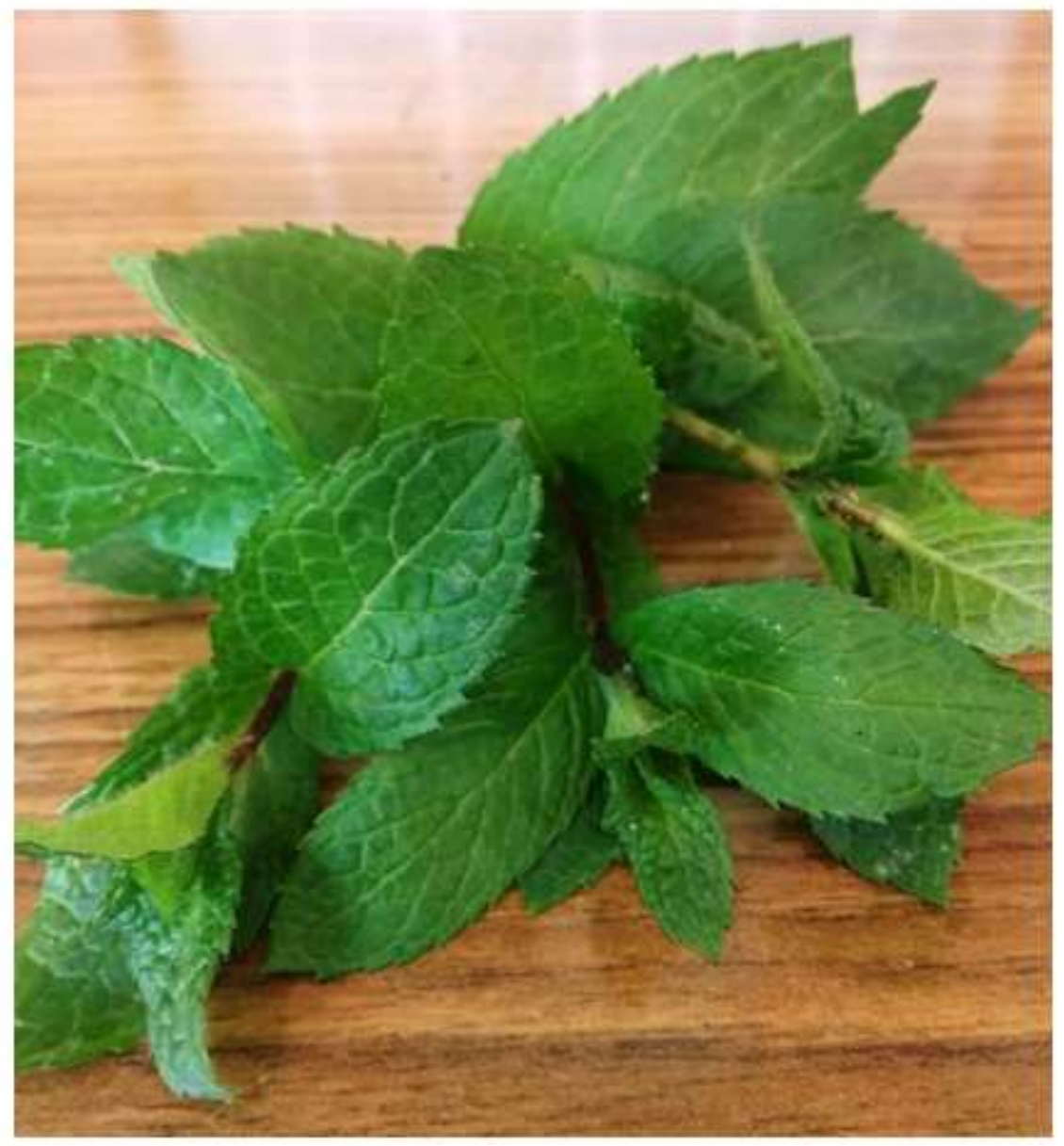

Figure 1

Fresh Mint 


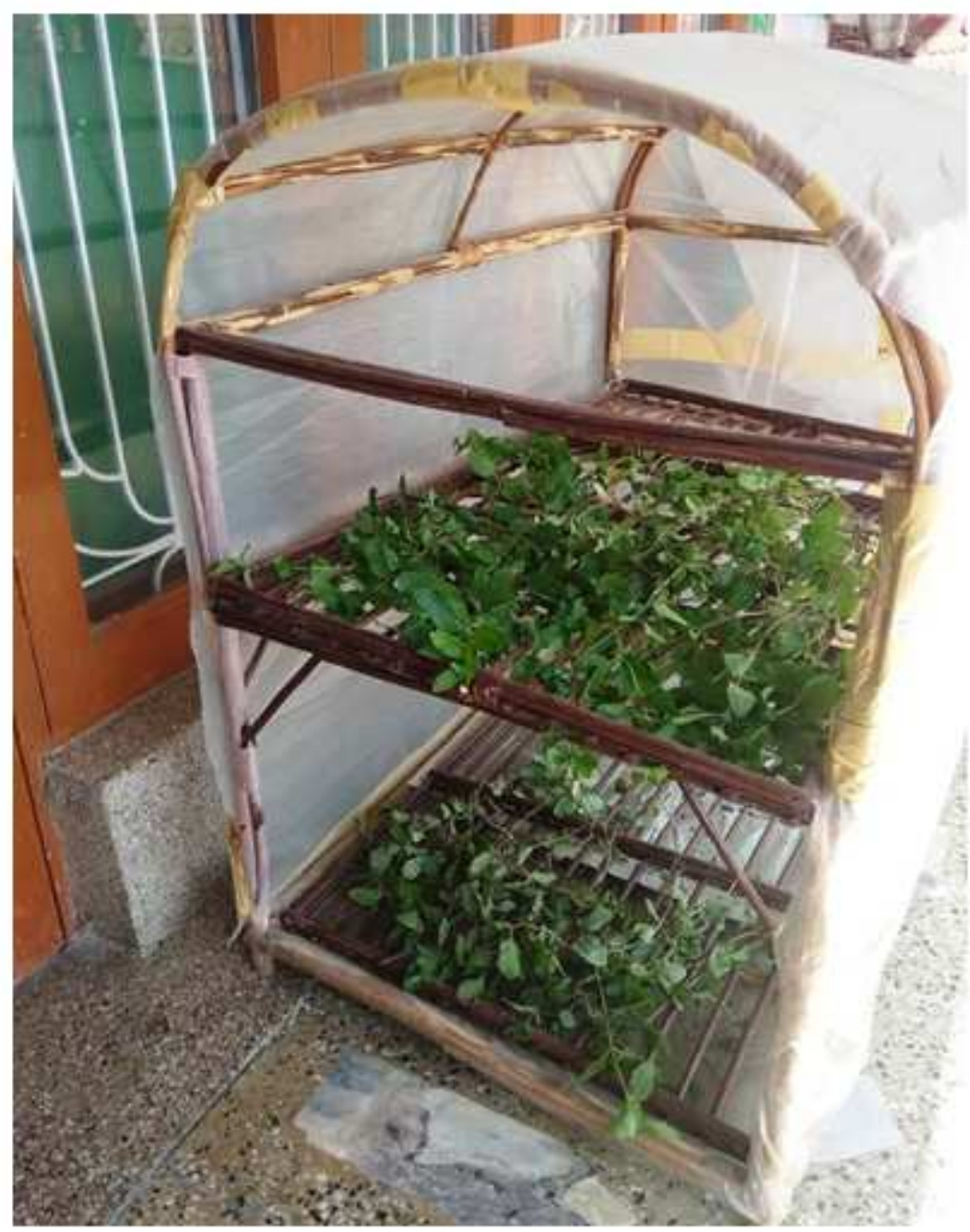

Figure 2

Mint drying in Solar Dryer 


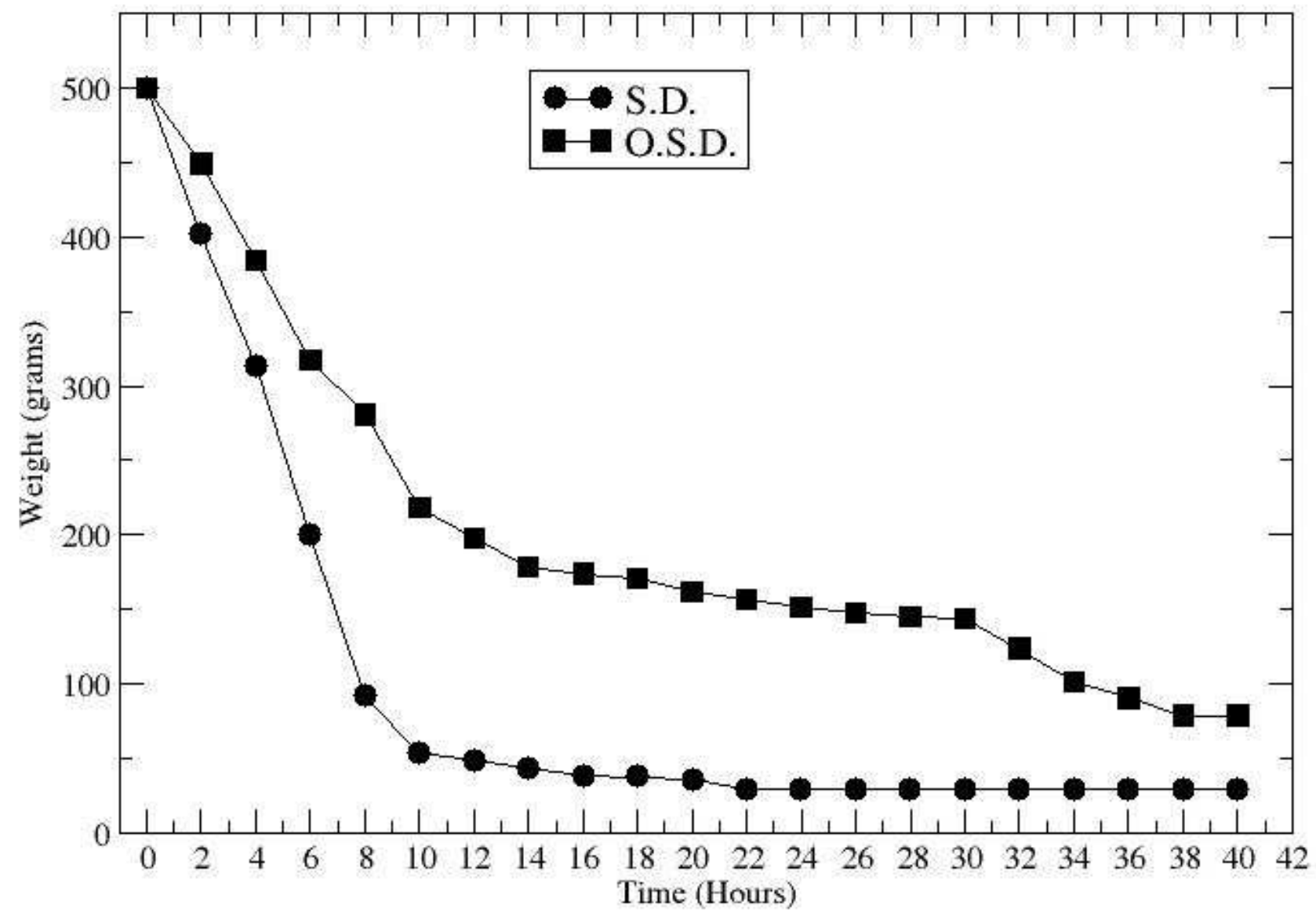

Figure 3

Variation of weight versus drying time 


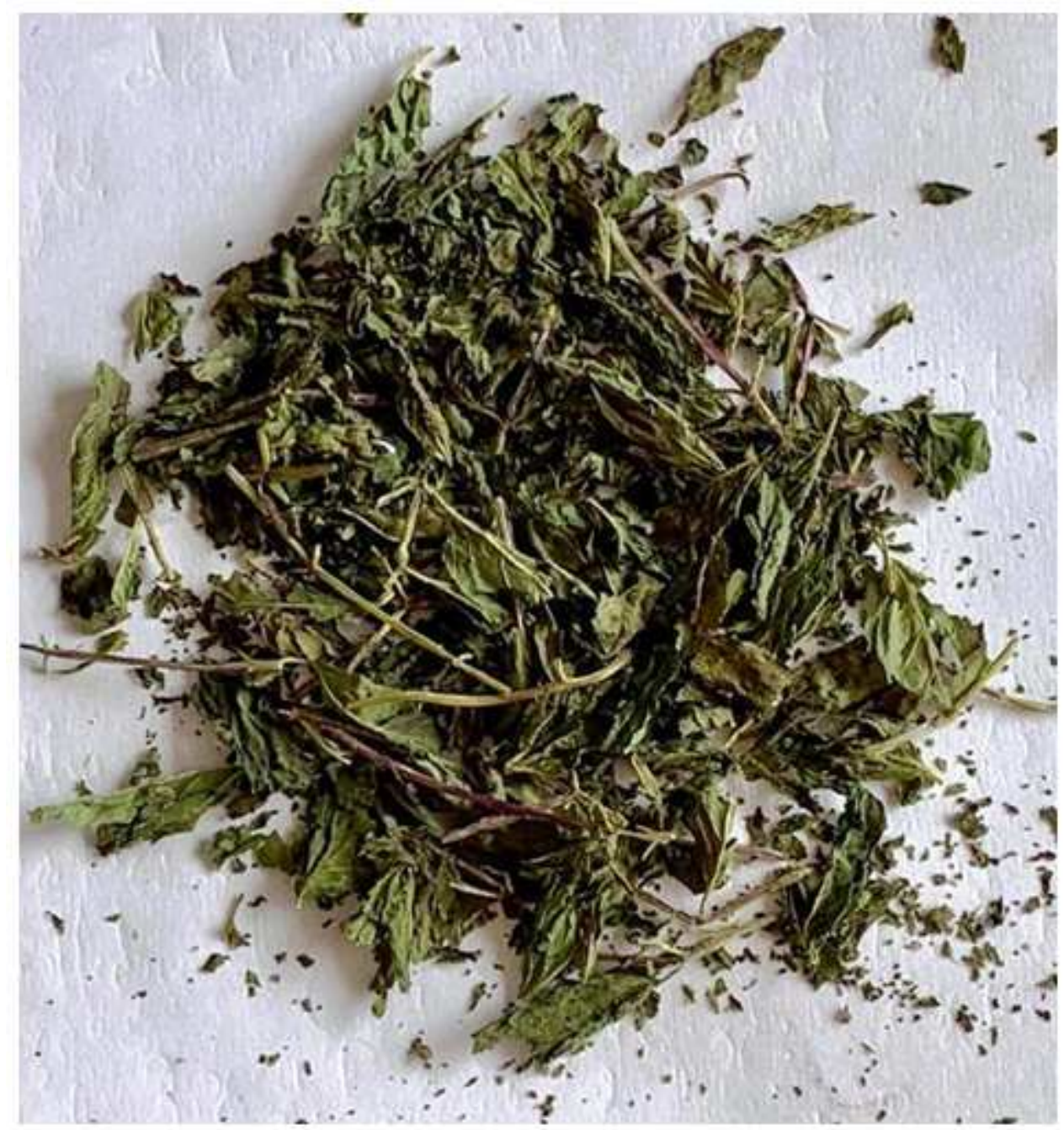

Figure 4

Solar Dried Sample 


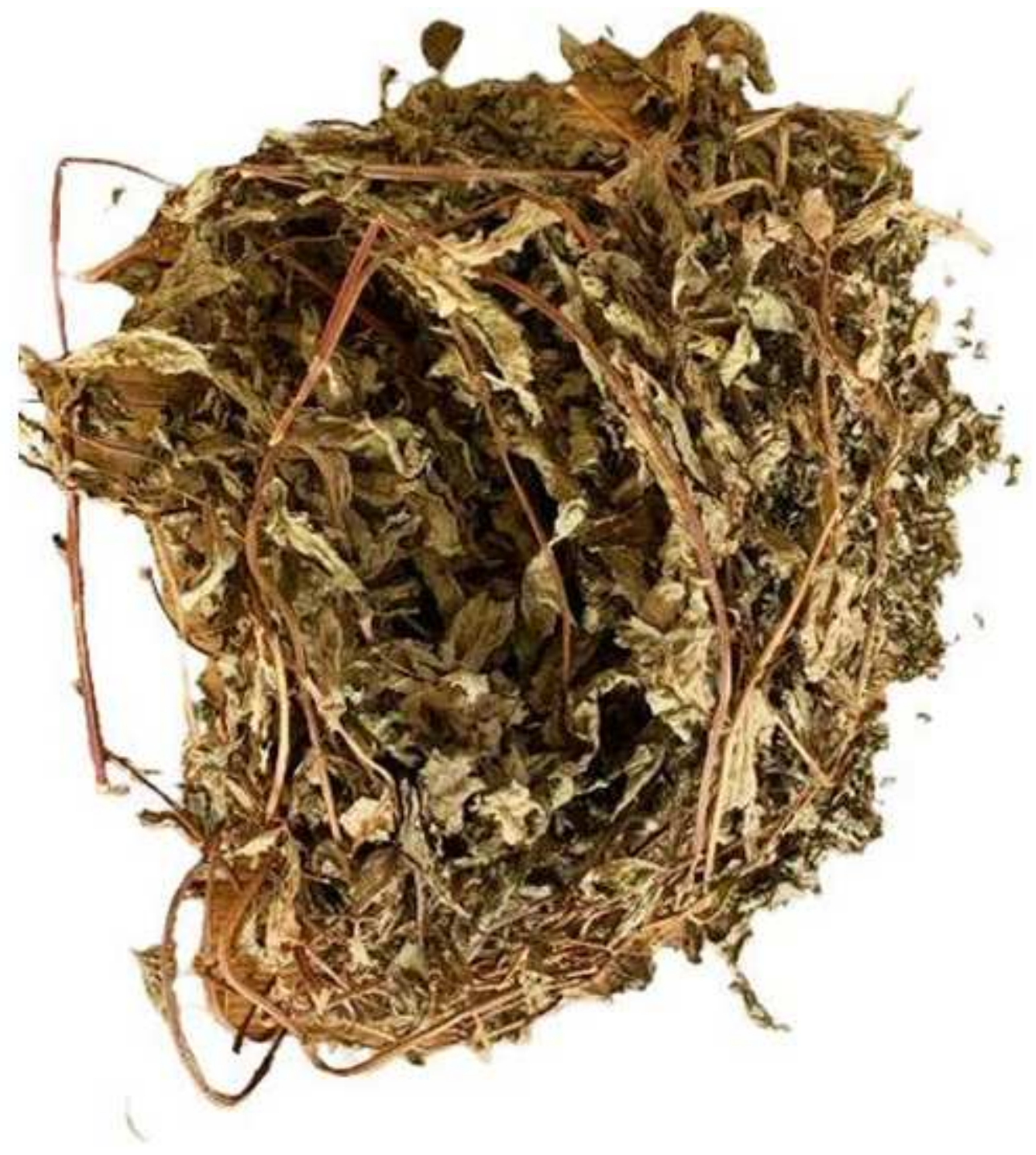

Figure 5

Open Sun Dried Sample 


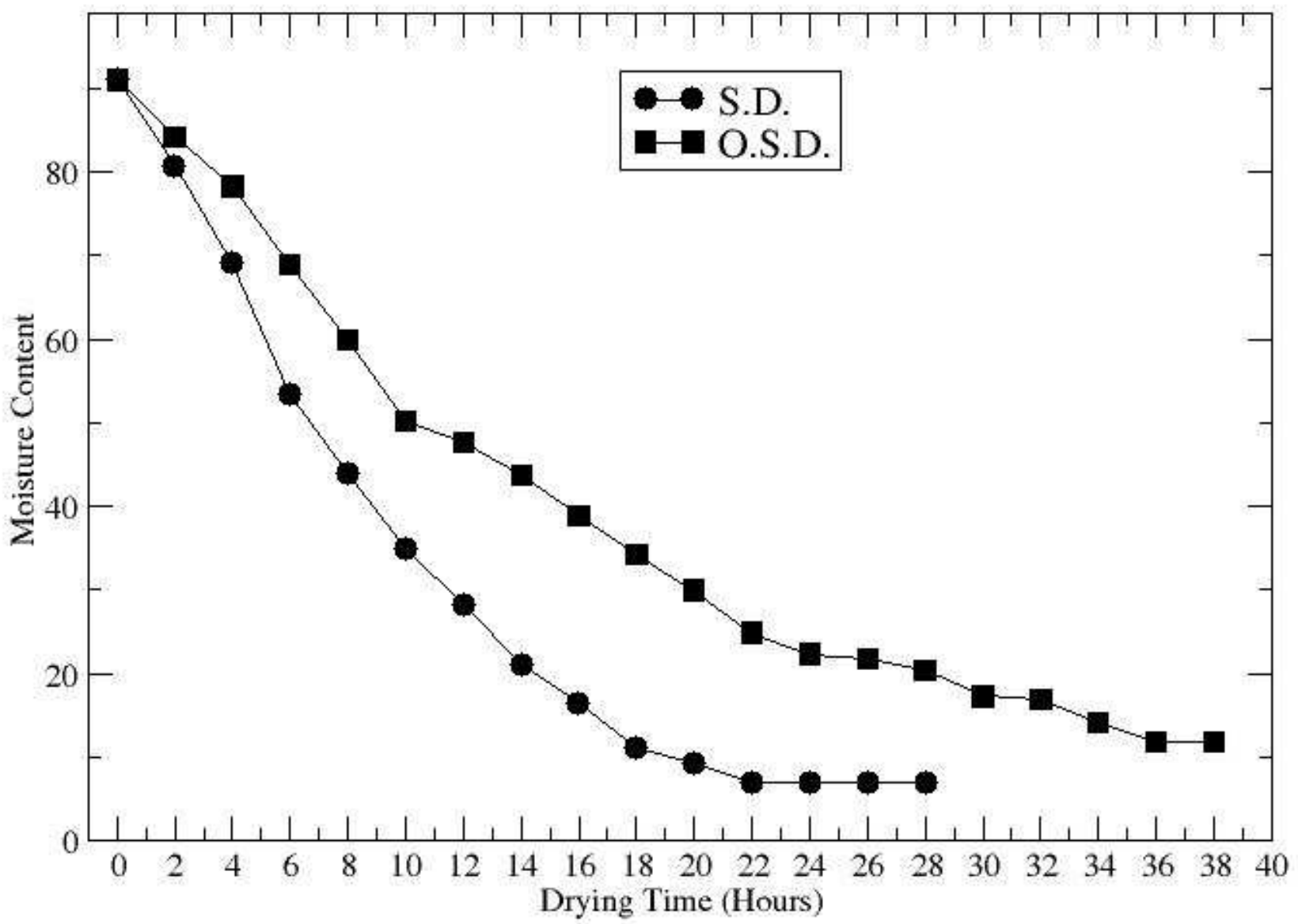

Figure 6

Variation in the moisture content of open sun dried sample and solar dried sample 


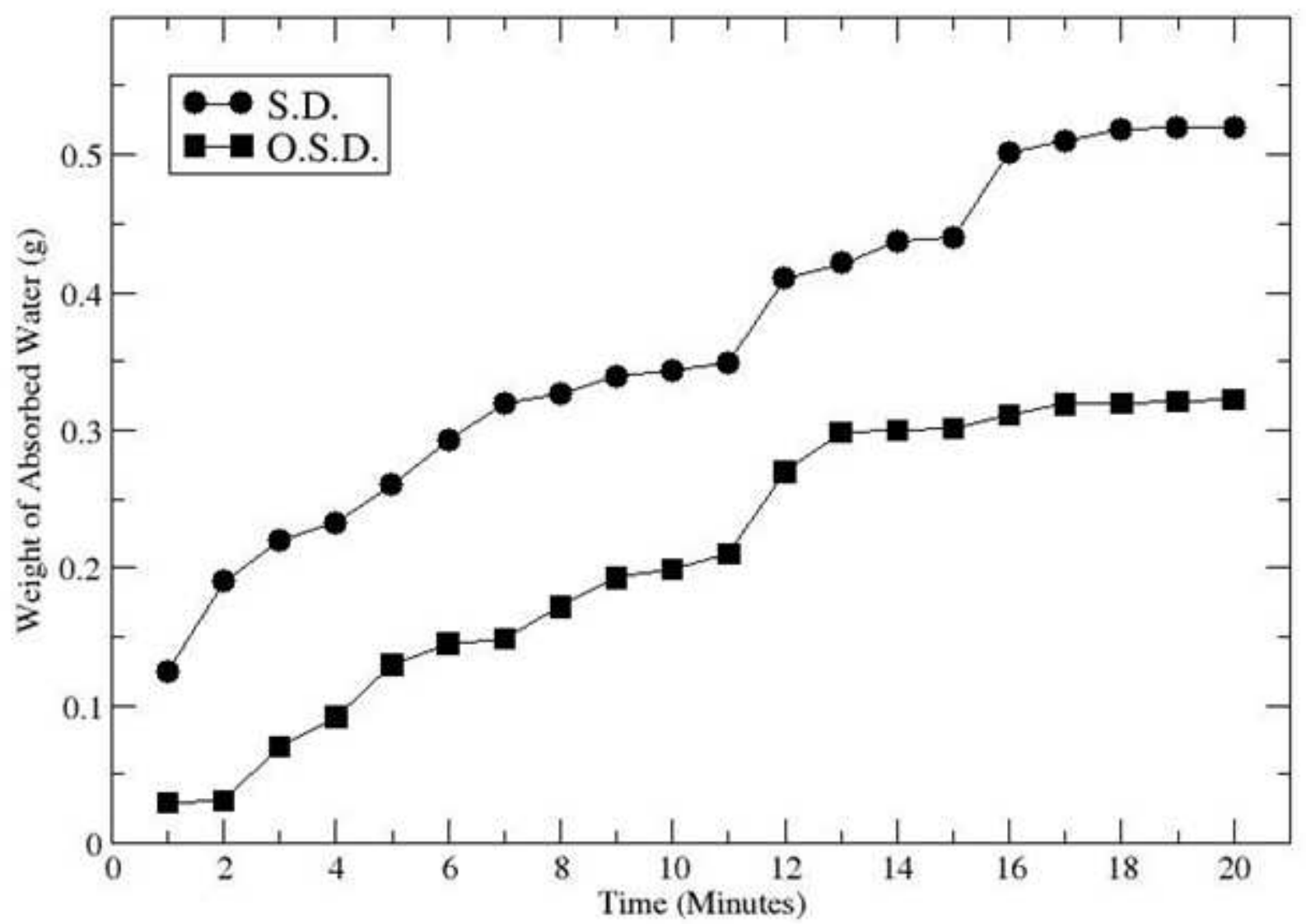

Figure 7

Rehydration value of solar dried and open sun dried samples. 


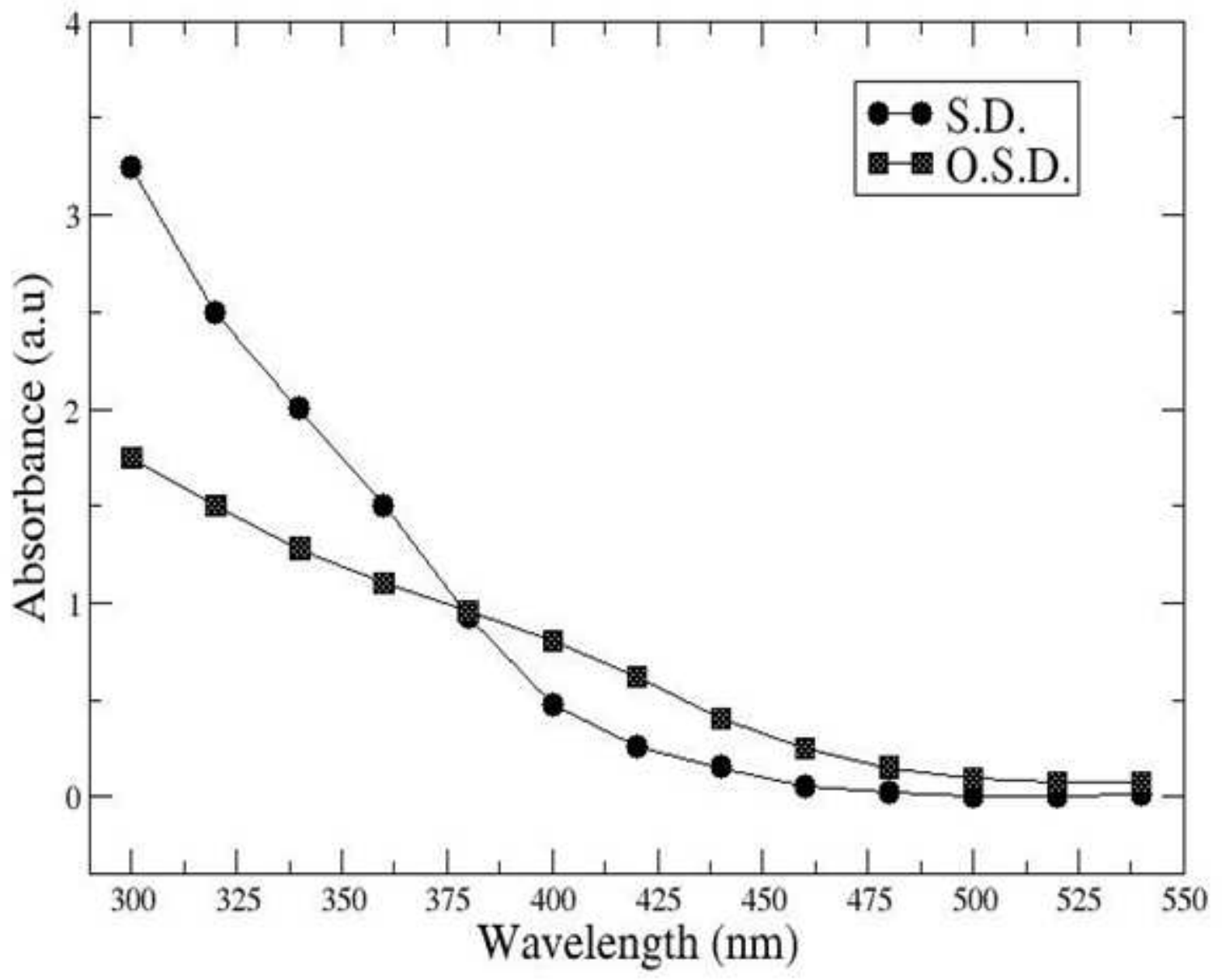

Figure 8

Variation of Absorbance with Wavelength indicating the transmittance. 